\title{
Thermal Resistance Evaluation of Raffia Palm Ash Concrete
}

\author{
*WILSON, UN; SANI, JE; ADEFILA, AA; MOHAMMED, IS
}

\author{
Department of Civil Engineering, Nigerian Defence Academy Kaduna, Nigeria. \\ *Corresponding Author Email: unwilson@nda.edu.ng
}

\begin{abstract}
This research attempts to empirically investigate the behavior of Raffia Palm Ash (RPA) concrete under elevated temperature of different percentages of RPA inclusion in the concrete. Raffia palm ash was obtained after the calcination of the raffia palm for 3 hours at $550^{\circ} \mathrm{C}$. X-ray Florescence (XRF) analysis performed revealed that the sample of Raffia Palm Ash (RPA) is a Class C pozzolana, which contains $51.8 \%$ of $\left(\mathrm{SiO}_{2}+\mathrm{Al}_{2} \mathrm{O}_{3}+\mathrm{Fe}_{2} \mathrm{O}_{3}\right)$ and has a specific gravity of 2.8. The compressive strengths were determined at $0{ }^{\circ} \mathrm{C}, 718{ }^{\circ} \mathrm{C}$ and $821{ }^{\circ} \mathrm{C}$ at 0 minutes, 15 minutes and 30 minutes respectively. The result revealed that workability of the concrete declined with the increment in the percentage of raffia palm ash in the concrete. The compressive strength of the concrete cubes as well decreased with the rise in temperature for the entire samples tested. The average loss in strength of the control $\left(0 \%\right.$ RPA) is about $15.3 \%$ at $718^{0} \mathrm{C}$ and $25.3 \%$ at $812^{\circ} \mathrm{C}$ while for Raffia palm ash concrete with $5 \%$ (optimum replacement) gives a minimum loss in strength of about $21.3 \%$ at $718^{\circ} \mathrm{C}$ and $28.5 \%$ at $812^{\circ} \mathrm{C}$, which is about $6 \%$ at $718^{\circ} \mathrm{C}$ and $13.2 \%$ at $812^{\circ} \mathrm{C}$, more than the control. The Scanning Electronic Microscopy (SEM) imaging indicates that the concrete subjected to temperature of about $821^{\circ} \mathrm{C}$ produces fewer flakes when compared to the concrete subjected to temperature of about $718^{\circ} \mathrm{C}$.
\end{abstract}

\section{DOI: https://dx.doi.org/10.4314/jasem.v25i3.23}

Copyright: Copyright (C) 2021 Wilson et al. This is an open access article distributed under the Creative Commons Attribution License (CCL), which permits unrestricted use, distribution, and reproduction in any medium, provided the original work is properly cited.

Dates: Received: 12 December 2020; Revised: 26 January 2021; Accepted: 12 February 2021

Keywords: Compressive strength, Raffia Palm Ash (RPA), Scanning Electron Microscopy (SEM), Thermal resistance, X-ray Florescence (XRF)

Concrete which is one of the man-made materials on earth is the most widely used in construction industries. It has been estimated that 1.7 cubic meters of concrete is consumed every year per person worldwide (Klee, 2009). Concrete is an important material used in any type of construction. Besides the important role that the concrete industry plays in the development of our society, it is also responsible for the production of $10 \%$ of the industrial carbon dioxide $\left(\mathrm{CO}_{2}\right)$ emission to the environment. Only the production of cement, which is the most important constituent of concrete, is contributing $6 \%$ of the global $\mathrm{CO}_{2}$ emission (Cement Industry Federation, 2003). The global $\mathrm{CO}_{2}$ emission is severely affecting the earth's temperature, which causes climatic changes and global warming related issues (Humphreys and Mahasenan, 2002). Among the different technologies, the most effective way to reduce $\mathrm{CO}_{2}$ emission is to minimize the use of clinker by substituting it partially with supplementary cementitious material (Ogbeide, 2012). Supplementary cementitious materials (SCMs) are materials that when used with Portland cement contribute to the properties of the hardened concrete through hydraulic or pozzolanic activity or both (Nabil and Simon, 2005). Some of the commonly used supplementary cementing materials are fly ash, silica fume, blast furnace slag and rice husk ash
(Amudhavalli and Mattew, 2012). Raffia Palm Ash is used in this research. Raffia Palm Ash (RPA) is got from the calcination of Raffia Palm fibre either by furnace or open burning. Raffia fibre is obtained from raffia palm. According to Robert \& Shedrack (2016) the Raffia fibre is soft, pliable and non-shrinking when wet. The generic name of raffia is 'raphis', meaning needlelike, describing the pointed structure of its fruits. Raffia palm exists in about twenty different species. Palm trees especially Raffia thrive in tropical Africa. In most parts of southern Nigeria, raffia is widely abundant and of relatively low cost. Fire outbreaks in buildings have been a major concern in the world today. The integrity of concrete is usually questioned due to the fact that after fire outbreak, the strength of the concrete reduces considerably. Fire resistance of concrete is the residual compressive strength of the concrete after exposure to high temperature for specific time duration (Umasabor and Okovido, 2018). One of the methods of improving fire resistance of concrete is by cement replacement with pozzolanic material (Aydin, 2008). Structures need to be designed such that in case of fire outbreak, the safety margin of the structure is improved and there is enough time for the occupants to escape or be given help (Umasabor and Okovido, 2018). Hence, it is very important to understand the effect of different 
temperature exposure on Raffia Palm Ash concrete as fire resistance is one of the major factors needed to be considered while designing.

\section{MATERIALS AND METHODS}

The materials used for the research include the following:

Raffia Palm Ash (RPA): The Raffia palm was collected from a farmland. The leafs were removed and the fibre was calcined to ashes at a temperature of $550^{\circ} \mathrm{C}$ in a muffle furnace at the laboratory of the Department of Mechanical Engineering, Kwara State Polytechnic, Ilorin, Kwara State. The XRF analysis on the calcined RPA was carried out at NASENI Center of Excellence, Nanotechnology and Advanced Material, Akure, Ondo State. The ash was further ground to required fine particles with a milling machine and sieved through a standard sieve of 75 microns. Plate 1a and $1 \mathrm{~b}$ show Raffia Palm before calcination and Calcined Raffia Palm Ash.

Cement: The cement used for the production of the concrete samples is Ordinary Portland cement (OPC); grade 42.5R which conforms to NIS 444-1:2003.

Aggregate: Fine aggregate (natural river bed sand) that passes through sieve $4.75 \mathrm{~mm}$ and coarse aggregate (crushed stone) of maximum size of $19 \mathrm{~mm}$ was used and both conform to BS 882:1992.

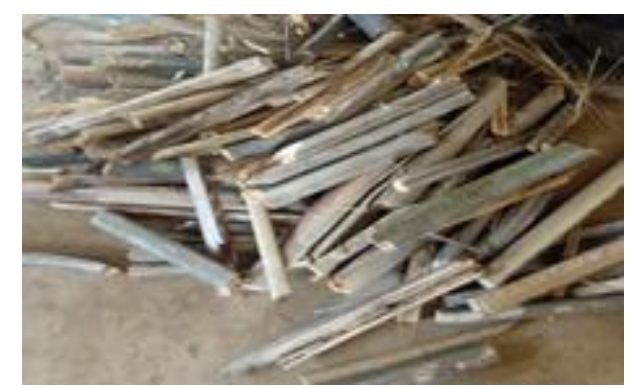

Plate 1a: Raffia Palm before Calcination

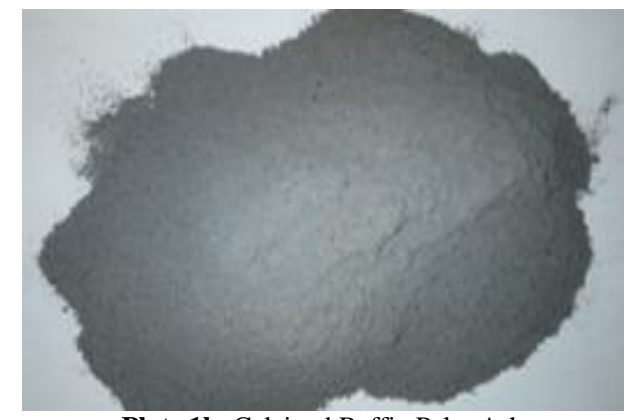

Plate 1b: Calcined Raffia Palm Ash

A prescribed mix, 1:1.5:3 with water-cement ratio 0.59 targeting a concrete strength of class C20/C25 was adopted after some trial mix tests. Raffia Palm Ash was added to concrete as pozzolana at $0 \%, 5 \%$, $10 \%, 15 \%, 20 \%$ and $25 \%$ by weight of cement and a $100 \times 100 \times 100 \mathrm{~mm}$ concrete cubes were cast for a concrete with a characteristic strength of $20 \mathrm{~N} / \mathrm{mm}^{2}$. Slump test was carried out on the fresh concrete to obtain the workability of the concrete in conformity to BS EN 12350-2 (2009) after which the concrete cubes were cured for 28 days. Afterwards, they were subjected to electric furnace at the mechanical engineering workshop of the Nigerian Defence Academy Kaduna, Nigeria. The cubes were heated to a temperature of $718^{\circ} \mathrm{C}$ and $821^{\circ} \mathrm{C}$ for 15 minutes and 30 minutes respectively in conformity with ISO 834-1 (1999), fire curve. The cubes density was obtained in conformity with BS EN 12390-7 (2009), after which the cubes were tested for compressive strengths following the stipulations in BS EN 12390-3(2009). The Scanning Electron Microscopy (SEM) analysis of the crushed cube for control and optimum replacement was carried out in the laboratory of the Chemical Engineering Department, Ahmadu Bello University (ABU), Zaria.

\section{RESULTS AND DISCUSSION}

Preliminary Tests on RPA, OPC and Aggregate: The preliminary tests carried out include XRF analysis, specific gravity, and consistency, setting time, fineness, particle size distribution and SEM. The tests were carried out in accordance with the provision of ASTM C 618 (2008), BS 1377:2 (1990), BS EN 1963 (1995), and ASTM C786/C786M-17, BS 812-103.1 (1985) respectively. The results are presented in the Tables 1 to 5. Table 1 shows that the OPC used for this study met the requirement of BS 12 of 1990 . Table 2 shows that the RPA used met the requirement of fineness and specific gravity to be used as a concrete material.

\begin{tabular}{llll}
\multicolumn{3}{c}{ Table 1: Characterization of the used cement } \\
\hline Test & Result & $\begin{array}{l}\text { Code } \\
\text { Specification }\end{array}$ & Code \\
\hline $\begin{array}{l}\text { Fineness } \\
\text { Initial }\end{array}$ & 0.0354 & $0.01-0.06$ & BS 12: 1990 \\
$\begin{array}{l}\text { Setting time } \\
\text { Final Setting }\end{array}$ & $\begin{array}{l}\text { 2hours } 32 \\
\text { minutes }\end{array}$ & $\leq 45$ Minutes & BS 12: 1990 \\
time & $\begin{array}{l}\text { mours } \\
\text { Consistency }\end{array}$ & $28 \%$ & BS 12: 1990 \\
$\begin{array}{l}\text { Specific } \\
\text { Gravity }\end{array}$ & 3.19 & 3.15 & BS 12: 1990 \\
\end{tabular}

\begin{tabular}{|c|c|c|c|}
\hline \multicolumn{4}{|c|}{ Table 2: Characterization of the RPA } \\
\hline Test & Result & $\begin{array}{l}\text { Code } \\
\text { Specification }\end{array}$ & Code \\
\hline Fineness & 0.06 & $0.01-0.06$ & $\begin{array}{l}\text { BS 12: } \\
1990\end{array}$ \\
\hline $\begin{array}{l}\text { Specific } \\
\text { Gravity }\end{array}$ & 2.80 & $2.3-2.9$ & $\begin{array}{l}\text { BS 12: } \\
1990\end{array}$ \\
\hline
\end{tabular}


The result on Table 3 shows that the sum of the combination of the chemical compounds $\left(\mathrm{SiO}_{2}, \mathrm{Al}_{2} \mathrm{O}_{3}\right.$, and $\mathrm{Fe}_{2} \mathrm{O}_{3}$ ) was found to be $51.8 \%$, which meets up with the specification of ASTM C610 of $50 \%$ or $70 \%$ for pozzolanas. The Raffia Palm Ash falls under the class $\mathrm{C}$ mineral admixture and thus can be considered as a pozzolanic material. The result in Table 4 shows that all percentage replacement used conform to the minimum initial time and maximum final time specified by ASTM C- 150 (1999), which prescribes a minimum of 45 minutes for initial setting time and a maximum of 600 minutes for final setting time. The result in Table 5 also shows that the properties of the aggregate used met the ASTM C33 (ACI) and BS 12: 1990 code requirements.

Table 3: Oxide Composition RPA using XRF analysis

\begin{tabular}{ll}
\hline Content & Percentage \\
\hline $\mathrm{SiO}_{2}$ & 46.7 \\
$\mathrm{Al}_{2} \mathrm{O}_{3}$ & 3.1 \\
$\mathrm{Fe}_{2} \mathrm{O}_{3}$ & 2.0 \\
$\mathrm{CaO}$ & 12.0 \\
$\mathrm{~K}_{2} \mathrm{O}$ & 4.5 \\
$\mathrm{SO}_{3}$ & 1.6 \\
$\mathrm{MgO}$ & 1.6 \\
$\mathrm{P}_{2} \mathrm{O}_{5}$ & 2.1 \\
\hline
\end{tabular}

Table 4: Consistency and setting time of blended RPA

\begin{tabular}{llll}
\hline $\begin{array}{l}\text { Replacement } \\
\text { of OPC with } \\
\text { RPA (\%) }\end{array}$ & $\begin{array}{l}\text { Consistency } \\
(\%)\end{array}$ & $\begin{array}{l}\text { Initial } \\
\text { setting } \\
\text { time } \\
\text { (Minutes) }\end{array}$ & $\begin{array}{l}\text { Final } \\
\text { setting } \\
\text { time } \\
\text { (Minutes) }\end{array}$ \\
\hline 5\% RPA & 30 & 92 & 180 \\
$10 \%$ RPA & 33 & 110 & 220 \\
15\% RPA & 36 & 170 & 265 \\
20\% RPA & 37 & 140 & 236 \\
25\% RPA & 37.5 & 125 & 211 \\
\hline
\end{tabular}

\begin{tabular}{lclll}
\multicolumn{5}{c}{ Table 5: Properties of the used fine aggregate } \\
\hline Test & Result & $\begin{array}{l}\text { Code } \\
\text { Specification }\end{array}$ & Code & \\
\hline $\begin{array}{l}\text { Fineness } \\
\text { Modulus }\end{array}$ & 2.82 & $2.3-3.1$ & $\begin{array}{l}\text { ASTM } \\
\text { (ACI) }\end{array}$ & C33 \\
Specific Gravity & 2.53 & $2.3-2.9$ & BS 12: 1990 \\
\hline
\end{tabular}

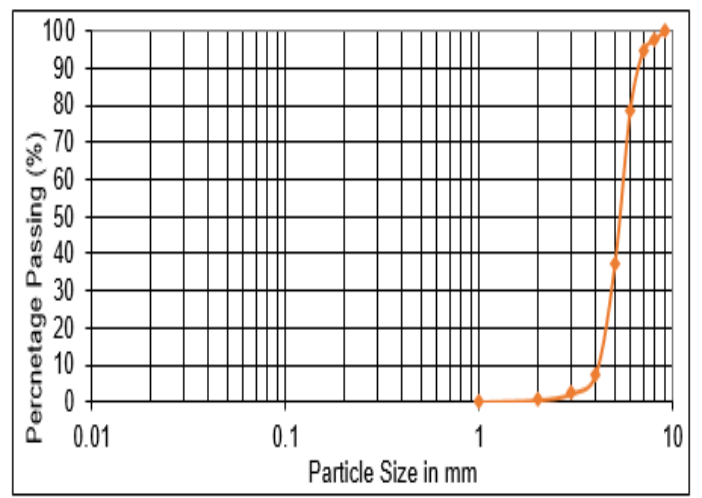

Figure 1: Sieve analysis for fine aggregate

The result in Figure 1 indicates that all the tested properties on fine aggregate fall within limits specified by the respective codes.
Workability Test of Fresh Concrete: The slump height values presented in Figure 2 reduce as the percentage of Raffia Palm Ash by weight of cement increases. The slump height between $0 \%$ and $15 \%$ falls into the category of a true slump while $20 \%$ and $25 \%$ are zero slump.

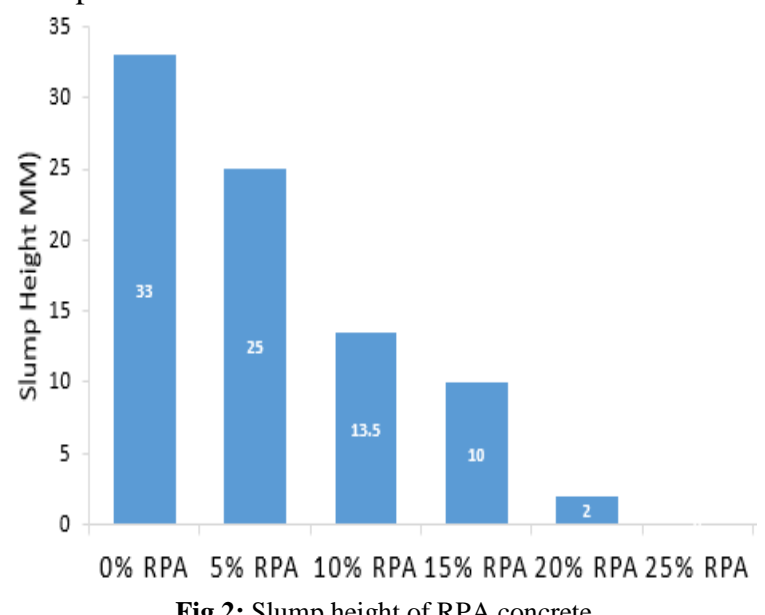

Fig 2: Slump height of RPA concrete

Density Test of Raffia Palm Ash Concrete: The density of concrete cubes after 28 days was obtained and presented in table 6 . The results show that at 28 days curing, peak density was obtained at $10 \%$ RPA and $25 \%$ RPA while when burnt at $718^{\circ} \mathrm{C}$ and $821^{\circ} \mathrm{C}$, the peak density was obtained at $10 \%$ RPA. This signifies that there was a decrease in the density of the concrete with increase in RPA especially beyond 10\% RPA.

Table 6: Density of Raffia Palm Ash Concrete cubes

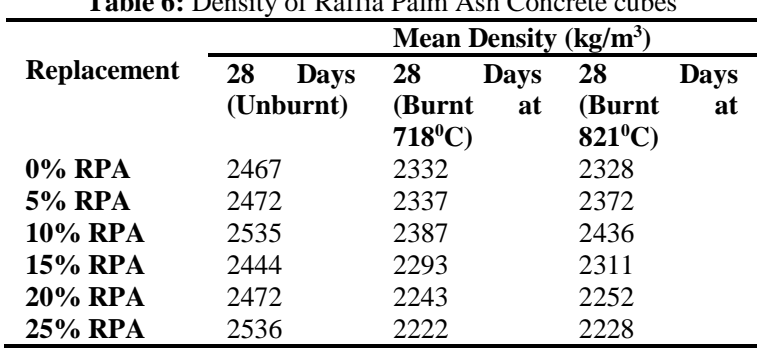

All cubes produced fall within the range of $2222 \mathrm{~kg} / \mathrm{m}^{3}-2536 \mathrm{~kg} / \mathrm{m}^{3}$

Compressive Strength Test of Raffia Palm Ash Concrete: The compressive strength of concrete cubes was obtained and presented in table 7 and the graphical representation of the compressive strength is presented in Figure 3. The compressive strength for the un-burnt RPA reduces with increase in percentage of RPA and the target strength of above C25 was achieved at RPA percentage up to $15 \%$, also, above $15 \%$ a strength less than $25 \mathrm{~N} / \mathrm{mm}^{2}$ was achieved. Similar results were obtained by Vashisht and Paliwal (2020); Sani et al, (2020) and Premalatha et al., (2016) for which a different pozzolanic material on concrete was used. 
The compressive strength of burnt concrete at $718^{\circ} \mathrm{C}$ at 15 minutes and $821^{\circ} \mathrm{C}$ at 30 minutes also show a decreasing in strength with increase in RPA content. The target strength of $25 \mathrm{~N} / \mathrm{mm}^{2}$ was achieved at $10 \%$ RPA for concrete burnt at $718^{\circ} \mathrm{C}$ for 15 minutes, whereas at $821^{\circ} \mathrm{C}$ for 30 minutes, the target strength was achieved at only 5\% RPA. From the result, it can be deduced that at higher temperature and longer duration of burning, minimum percentage of RPA is required for the integrity of the concrete to be maintained. The result also shows that RPA concrete with not more than $10 \%$ addition has the tendency of thermal resistance. Similar results were obtained by Teja and Meena (2018); Aydin (2008); and Prasad et al.(2008), for which different Pozzolanic material on concrete were used.

Table 7: Compressive Strength of RPA Concrete

\begin{tabular}{llll}
\hline \multirow{2}{*}{ Replacement } & \multicolumn{2}{l}{$\begin{array}{l}\text { Mean Compressive Strength at 28 Days } \\
\left(\mathbf{N} / \mathbf{m m}^{2}\right)\end{array}$} \\
\cline { 2 - 4 } & Unburnt & $\begin{array}{l}\mathbf{7 1 8}^{\mathbf{0}} \mathbf{C} \text { at } \mathbf{1 5} \\
\text { minutes }\end{array}$ & $\begin{array}{l}\mathbf{8 2 1}^{\mathbf{0}} \mathbf{C} \text { at } \mathbf{3 0} \\
\text { minutes }\end{array}$ \\
0\% RPA & 38.7 & 32.8 & 28.9 \\
5\% RPA & 37.1 & 29.2 & 26.5 \\
10\% RPA & 35.4 & 25.1 & 21.1 \\
15\% RPA & 34.0 & 23.5 & 18.7 \\
20\% RPA & 24.6 & 17.2 & 14.3 \\
25\% RPA & 20.6 & 14.7 & 10.9 \\
\hline
\end{tabular}

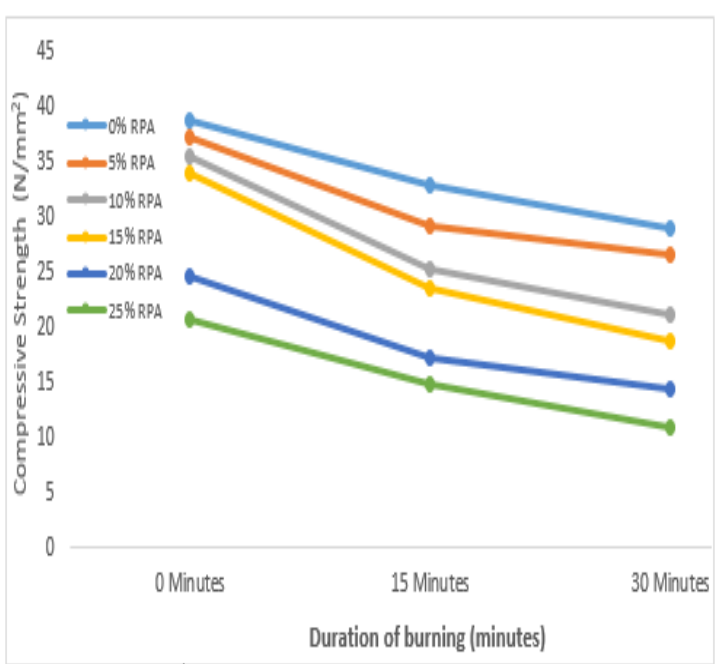

Fig 3: Compressive strength of RPA concrete

Two-way Analysis of Variance (ANOVA): Two way analysis of variance tests was carried out to determine the level of significance of the percentage replacement of RPA on the compressive strength of the concrete and also the significance level of the influence of burning temperature/time on the compressive strength of the concrete. Table 8 shows the result of the twoway analysis of variance.

Table 8: Two-Factor without Replication for burnt Concrete Cubes

\begin{tabular}{|c|c|c|c|c|c|c|}
\hline SUMMARY & Count & Sum & Average & Variance & & \\
\hline 0 minute at zero degree & 6 & 190.4 & 31.73333 & 54.15067 & & \\
\hline 15 minute at 718 degree & 6 & 142.5 & 23.75 & 47.659 & & \\
\hline 30 minutes at 821 degree & 6 & 137 & 22.83333 & 16.85867 & & \\
\hline $0 \%$ RPA & 3 & 100.4 & 33.46667 & 24.34333 & & \\
\hline $5 \%$ RPA & 3 & 92.8 & 30.93333 & 30.34333 & & \\
\hline $10 \%$ RPA & 3 & 81.6 & 27.2 & 54.43 & & \\
\hline $15 \%$ RPA & 3 & 76.2 & 25.4 & 61.23 & & \\
\hline $20 \%$ RPA & 3 & 64.5 & 21.5 & 14.77 & & \\
\hline $25 \%$ RPA & 3 & 54.4 & 18.13333 & 9.403333 & & \\
\hline \multicolumn{7}{|l|}{ ANOVA } \\
\hline Source of Variation & SS & Df & MS & $\mathbf{F}$ & P-value & F crit \\
\hline Burning time/temperature & 287.5678 & 2 & 143.7839 & 14.16978 & 0.001207 & 4.102821 \\
\hline RPA Content & 491.8694 & 5 & 98.37389 & 9.694662 & 0.001363 & 3.325835 \\
\hline Error & 101.4722 & 10 & 10.14722 & & & \\
\hline Total & 880.9094 & 17 & & & & \\
\hline
\end{tabular}

The result shows that effect of burning time/temperature and Raffia Palm Ash replacement on the compressive strength is statistically significant since $\mathrm{F}_{\mathrm{CAL}}=14.17>\mathrm{F}_{\mathrm{CRIT}}=4.10$ for burning time/temperature and $\mathrm{F}_{\mathrm{CAL}}=9.69>\mathrm{F}_{\mathrm{CRIT}}=3.33$ for RPA replacement. The effect of the burning time on compressive strength is more pronounced than that of Raffia Palm Ash replacement.

Scanning Electron Microscopy (SEM) Analysis: The result of SEM analysis of RPA concrete at 300x magnification is presented in Plate $2-7$.

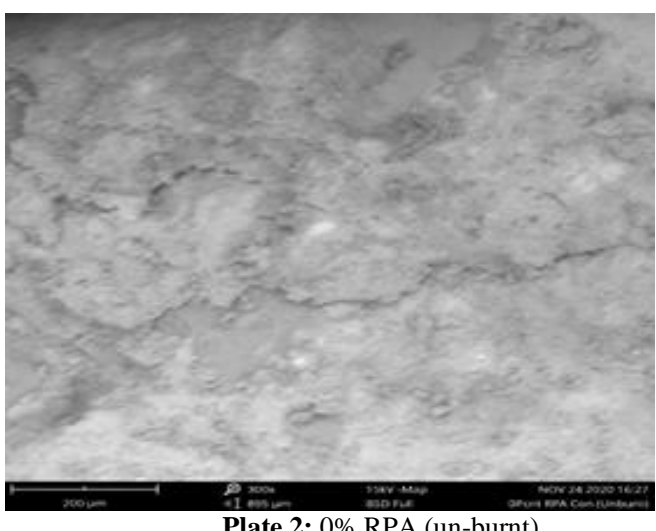

Plate 2: 0\% RPA (un-burnt) 


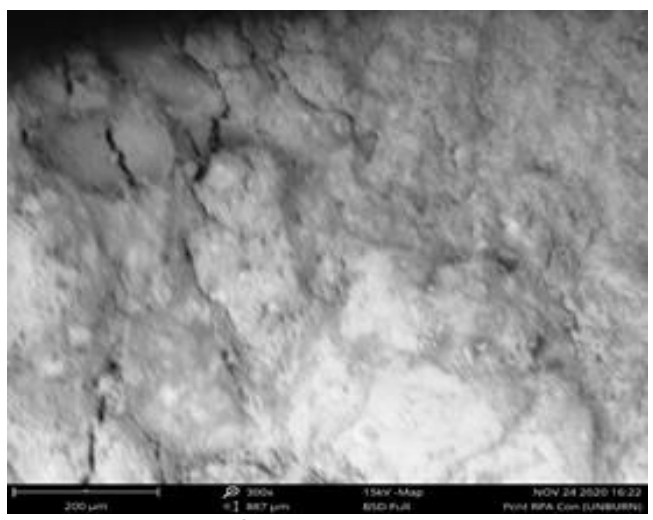

Plate 3: 5\% RPA (un-burnt)

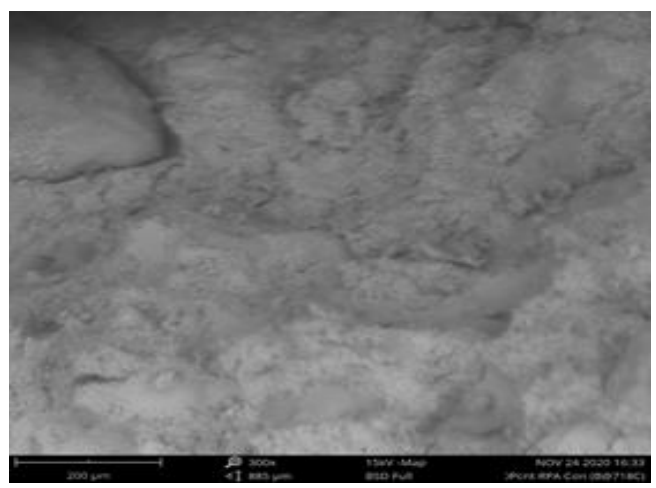

Plate 4: 0\% RPA (burnt at $718^{\circ} \mathrm{C}$ )

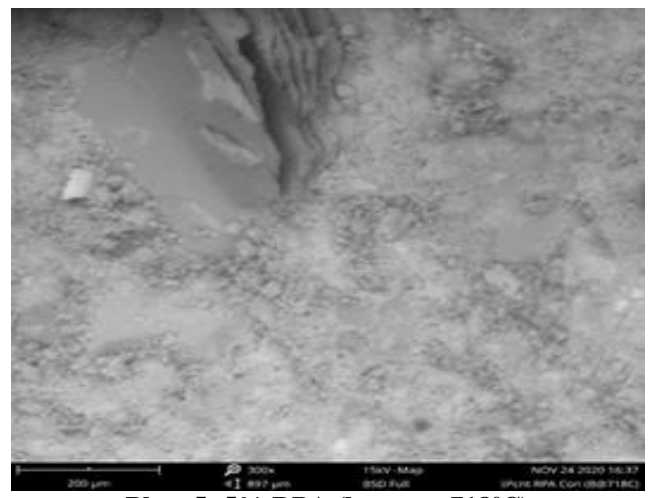

Plate 5: 5\% RPA (burnt at $718^{\circ} \mathrm{C}$ )

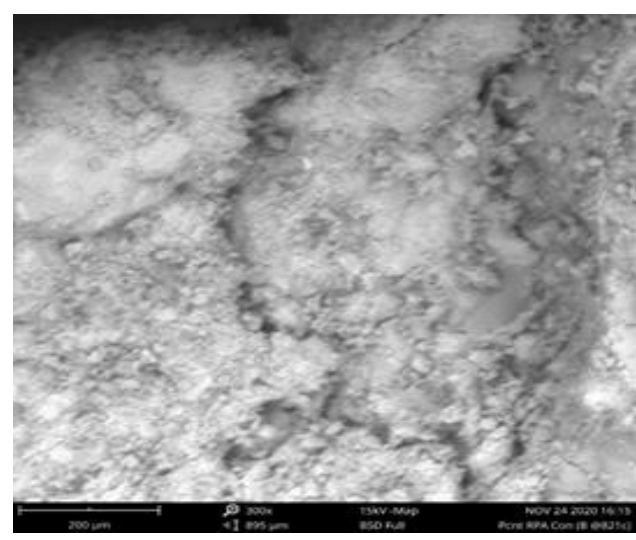

Plate 6: $0 \%$ RPA (burnt at $821^{\circ} \mathrm{C}$ )

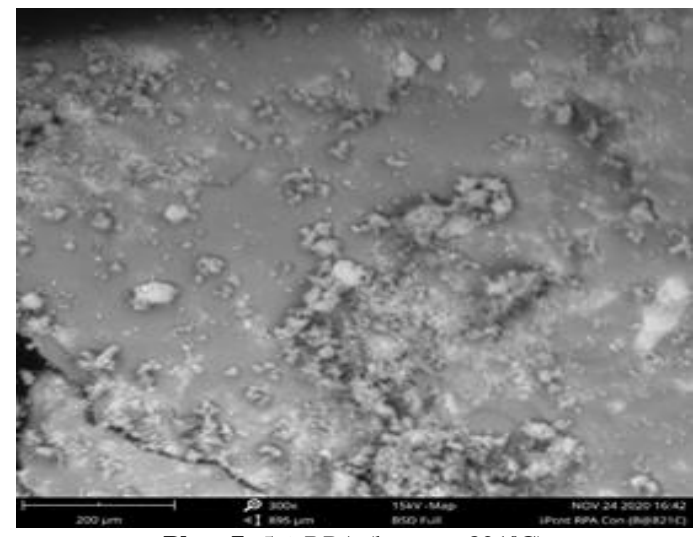

Plate 7: 5\% RPA (burnt at $821^{\circ} \mathrm{C}$ )

The morphologies of all the samples is a backscattered electron image of different ratio pastes with fume showing clear microstructural definition. There are clearly defined boundaries between unreacted cement grains (the bright particles) and reaction products (gray phases), as well as between the large pores and reaction products. The effect of burning was observed as 5\% of Raffia Palm Ash concrete (unburnt) has micro-cracks devoid of pores and do not produce any harmful effect on them or the rest of the features in the image. The concentration of Raffia Palm Ash affects the concrete structure as more pores are opened, noticeable voids present were observed. It was also observed that concrete subjected to temperature of $821^{\circ} \mathrm{C}$ produces fewer flakes when compared to the concrete subjected to temperature of $718^{\circ} \mathrm{C}$ which gives room for more flakes. The SEM micrograph in plate 2 and 3 show that C-S-H gel was vastly spread on the mixture of hydrated cement paste which was the main cause for the effective strength. Formation of Portlandite $\mathrm{Ca}(\mathrm{OH})_{2}$ and Calcite $\left(\mathrm{CaCO}_{3}\right)$ was visualized all over the exterior surface of the hydrated cement paste (See Plate 2) and also as a result of the RPA in the mix (See Plate 3). The distribution of C-S-H was nearly decreased as the percentage of RPA increases and as the temperature of burning increase (See Plate $4-7$ ) which is responsible for the decrease in strength of the concrete. Similar results were obtained by Adithya Saran and Magudeswaran, (2017); Manuel et al., (2019) and Imtiaz et al., (2020) where different pozzolanic material on concrete were used.

Conclusion: There is a general reduction in the compressive strength of all concrete cubes with increase in temperature. However, the reduction in the optimum replacement (5\%RPA) is within the limit of the control, which justifies the use of RPA as partial replacement. The concrete subjected to temperature of about $821^{\circ} \mathrm{C}$ produces fewer flakes and decrease in C$\mathrm{S}-\mathrm{H}$ gel when compared to those subjected to 
temperature of about $718^{\circ} \mathrm{C}$. The SEM results also show how the strength of concrete decreases with burning temperature.

Acknowledgement: With pain, we wish to acknowledge the tremendous scholarship of Late Dr. J. O. Afolayan who initiated this research concept and therefore dedicate the entire work to his loving memory.

\section{REFERENCES}

Adithya, AS; Magudeswaran, P. (2017). SEM Analysis on Sustainable High Performance Concrete. Intern. J. of Innov. Res. in Sci., Engg and Tech. 6(6):10237 - 10246.

Amudhavalli, N; Mattew, J (2012). Effects of Silica fume on strength and durability parameters of concrete. Intern. Journ. of Engg. Sci. \& Emerging Techn. 3(1): 28-35.

ASTM C33 (2008). Standard Specification for concrete aggregate. America Standard of Testing Materials International, West Conshohocken.

ASTM C618 (2008). Standard Specification for coal fly ash and raw or calcined natural pozzolan for use in concrete. America Standard of Testing Materials International, West Conshohocken.

ASTM C786-96 (2003). Standard Test Methods for Fineness of Hydraulic Cement and Raw materials. British Standard BSI Group Headquarters 389 Ciswick High Road, London, W4 4Al, UK, Standards Policy and Strategy Committee.

Aydin, S. (2008). Development of a high temperature resistant mortar by using slag and pumice . Fire Saj. J. 43, 610-617.

Bamigboye, G; Ngene, B; Aladesuru, O; Mark, O; Adegoke, D; Jolayemi, J (2019). Thermal Effects of Treated and Untreated coconut fibre (cocos nucifera) Reinforced concrete at varing temperatures.

BS: 12 (1971). Properties of cement. British Standard BSI Group Headquarters 389 Ciswick High Road, London, W4 4Al, UK, Standards Policy and Strategy Committee.

BS: 12 (1990). Specification for Portland cement British Standard BSI Group Headquarters 389
Ciswick High Road, London, W4 4Al, UK, Standards Policy and Strategy Committee.

BS 1377:2 . (1990). Methods of Test for Soil for Civil Engineering Purposes. British Standard BSI Group Headquarters 389 Ciswick High Road, London, W4 4Al, UK, Standards Policy and Strategy Committee.

BS 882. (1992). Specification for Aggregates from Natural Sources for Concrete. British Standard BSI Group Headquarters 389 Ciswick High Road, London, W4 4Al, UK, Standards Policy and Strategy Committee.

BS 812-103.1. (1985). Methods for Determination of Particle Size Distribution section 103.1 sieve tests. British Standard BSI Group Headquarters 389 Ciswick High Road, London, W4 4Al, UK, Standards Policy and Strategy Committee.

BS EN 12350-2. (2009). Testing Fresh Concrete Slump Test, British Standards.

BS EN 12390-3. (2009). Testing Hardened Concrete Compressive Strength of Test Specimens, British Standards.

BS EN 12390-7. (2009). Testing Hardened Concrete Density of Hardened Concrete, British Standards.

BS EN 196-3. (1995). Methods of Testing Cement Determination of Setting time and soundness. British Standard BSI Group Headquarters 389 Ciswick High Road, London, W4 4Al, UK, Standards Policy and Strategy Committee.

Cement Industry Federation. (2003). CIF Cement Industry Environment Report. Cement Industry Fedreation: Forrest, Australia.

Humphreys, K.; Mahasenan, M (2002). Toward a Sustainable Cement Industry: Climate Change. Substudy 8. World Bussiness Council for Sustainable Development (WBCSD): Geneva, Switzerland.

Imtiaz, T; Ahmed, A; Sahadat, MD; Faysal, M (2020). Microstructure Analysis and Strength Characterization of Recycled Base and Sub-Base Materials Using Scanning Electron Microscope. Infrastructures 5(70): $1-14$. 
ISO 834-1 (1999) Fire resistance. Test- Element of building construction.

Klee, H (2009). The cement sustainability initiative: Recycling concrete. Worlf Bussiness Council for sustainable Development (WBcSD): Geneva, Switzerland.

Manuel, J; Chinchillas-Chinchillas, CA; RosasCasarez, SP; Arredondo-Rea, JM; GómezSoberón; Ramón CH (2019). SEM Image Analysis in Permeable Recycled Concretes with Silica Fume. A Quantitative Comparison of Porosity and the ITZ. Materials 12 (22):01.

Nabil, B; Simon, F (2005). Use of Fly Ash and Slag in Concrete: A Best Practice Guide. Government of Canada Action Plan 2000 on climate change.

NIS 444-1. (2003). Composition, Specifications and Conformity Criteria for Common Cements. Nigeria Industrial Standards; Standards Organisation of Nigeria, Lagos, Nigeria.

Ogbeide, S (2012). Developing an Optimization Model for $\mathrm{CO}_{2}$ Reduction in cement Production Process. Intern. Journ. of Engg. Sci. and Tech. Rev. 85-88.

Prasad, J; Ahuja AK; Khan MS (2008). NBM\&CW, Infra Construction \& Equipment Magazine. http://www.nbmcw.com/techarticles/concrete/311-concrete-suitable-forhigher-temperature.html.

Premalatha, P; Vinodh, KR; Anto, LC; Nithiya R (2016). Properties of palm Ash Concrete. Intern. Journ. of Engg. Sci. Invent. 5(8): 29-32.

Robert, J; Shedrack, T (2016). Investigation of Thermal Conductivity of Raphia Fibre (Piassava). Raphia hookeri. Intern. Journ. Of App. Sci. \& Maths theory, 2, 11-17.

Sani, JE; Afolayan JO; Wilson, UN; Eze OC; Nyeri, J (2020). Experimental investigation of the effect of Sisal Fiber on the partially replaced cement with groundnut shell ash in concrete. J. Buildg. Mat. and Struc. 7: 255-261.

Teja, KV; Meena, T (2018). Study on Temperture Resistance concrete. Intern. J. Civil Eng. Tech. 9 (14):1229-1236.

Umasabor, RI; Okovido, JO (2018). Fire resistance evaluation of rice husk ash concrete. Heliyon 4, e01035.

Vashisht, P; Paliwal MC (2020). Partial Replacement of Cement with Rice husk ash in cement concrete, Inter. J. Eng. Res. Tech 9(12): 322-325. 